\title{
Exploring the Brand Experience of Recoletos Education: An Interpretative Phenomenological Analysis
}

\author{
Ernil F. Almayo, OAR \\ OAR Province of St. Ezekiel Moreno, Philippines \\ ernil25@yahoo.com \\ Myrna E. Juplo \\ University of Negros Occidental-Recoletos, Philippines
}

\begin{abstract}
This qualitative research using interpretative phenomenological analysis (IPA) explores the brand experience of Recoletos Education in the Philippines. Two levels of interpretation are generated: that of the participants who make sense of their brand experience as lived experience and that of the researcher who makes sense of the participants' interpretations. Validated transcripts from in-depth interviews reveal the participants' convergent and divergent interpretations of their brand experience. Rigid thematic analysis helps construct a master table of themes with four superordinate themes expressed through metaphors: the house on rock, the shepherd with his flock, the good fruit, and the strong winds and the big waves, and these, in turn, correspond to brand attributes, synergy and strategy, brand experience dimensions, and brand challenges, respectively. Finally, these themes reveal and comprise the single overarching theme: the key elements in the brand landscape of Recoletos Education.
\end{abstract}

Keywords: Brand Dimensions, Brand Experience, Interpretative Phenomenological Analysis (IPA), Lived Experience, Recoletos Education, Philippines

Date Submitted: February 23, 2019

Date Revised: June 15, 2019

Date Accepted: July 10, 2019

\subsection{Introduction}

Brand experience is so influential an offspring that like its progenitorexperience- has brought about Copernican revolution in "the marketplace of ideas and the world of commerce" (Pine \& Gilmore, 2013). As an object of study pioneered 
by Ortmeyer and Huber (1991 cited in Khan \& Rahman, 2015), brand experience was conceptualized as "subjective, internal consumer responses (sensations, feelings, and cognitions) and behavioral responses evoked by brand-related stimuli that are part of a brand's design and identity, packaging, communications, and environments" (Brakus, Schmitt, \& Zarantonello, 2009). Today, it continues to gain increased attention due to its relevance and impact in the field of brand management and of marketing (Chevtchouk, Veloutsou, \& Paton, 2017; Khan \& Rahman, 2015; Xixiang, Gilal, \& Gilal, 2016).

Among the studies that have attempted to expand the conceptualization of this construct were those of Al Mandil and Yen (2017); Andreini, Solerio, Pedeliento, and Zarantonello (2017); Chevtchouk et al. (2017), and Nysveen and Pedersen (2013).

Moreover, Khan and Rahman (2015) noted that most studies on brand experience were empirical and from developed countries. In Asia, the growing interest could be found most conspicuously in China, then, in Taiwan, Singapore, and India. The Philippines was not in the list. The authors also pointed out that the domain of educational sub-industry and the use of qualitative approaches as well as interpretive perspectives were left out in those studies. On this account, this study attempted to fill the gaps by utilizing IPA to brand experience.

A recently established method belonging to the hermeneutic tradition of phenomenology, IPA takes on a double hermeneutic wherein the participants try to make sense of their lived experience and the researcher tries to make sense of the participants trying to make sense of their lived experience (Smith, 2015; Smith, Flowers, \& Larkin, 2009).

Considerable school-related issues were already studied using IPA such as inclusive education (Opie, Southcott, \& Deppeler, 2017), bullying (Rodríguez, 2016), etc., but studies applying IPA to brand experience of a school brand taken together as a lived experience was quite difficult to find.

Fortunately, the study of Madrigal (2017) on the graduate attributes of a Recoletos school and that of Besana (2017) on St. Augustine's "Caritas et Scientia" ("Love and Knowledge") as the pillars of Recoletos Education could help illumine the issues related to the brand experience of Recoletos Education.

Having identified the existing gaps, I wished to pursue an IPA-based inquiry into the brand experience of Recoletos Education as a valuable contribution to the present international efforts of "revitalization and restructuring" in the Order of Augustinian Recollects (OAR), particularly in its school apostolate here in the Philippines.

\subsection{Literature Review}

A conceptual review of related literature revealed that school branding whose importance has been verified in all levels (Bock, Poole \& Joseph, 2014; DiMartino \& Jessen, 2014 cited in Varadarajan, 2016) is analogous to commercial branding in terms of process and design principles (Burton, 2017).

Etymologically, "brand", from the Old Norse, "brandr" meaning "to burn", evolved as to refer to the producers' practice of burning their mark (or brand) onto their products (Moore \& Reid, 2008). Although brand was defined as a "distinguishing symbol, name, logo, mascot, term, sign or design or a combination of them, projected 
to identify and differentiate the goods and services of one seller or group of sellers from those of competitors" (Gwal \& Gwal, 2016), it meant so much more.

Brand and branding are now part of the day-to-day vocabulary in the business world. They were even transported in the educational sub-industry, affecting significantly the parents' choice of schools for their children (Chen \& Chen, 2014; Malik, Mushtaq, Jaswal, \& Malik, 2015 cited in Varadarajan, 2016).

Consequently, several schools had to articulate their brand. Région Lasallienne de l'Amérique du Nord (RELAN) or Lasallian Region of North America rationalized the name "Lasallian Education" as its brand (RELAN, 2012). The Ateneo de Manila University (AdMU) also managed its own brand by standardizing its Visual Identity Device (VID) (Ateneo de Manila University, n. d.).

Among Catholic schools, the integration of the charism is a central issue (Burton, 2016). The Siena College in New York boasts of its Franciscan origin and integrates in its educational ministry the sacramental view of the world and an optimistic view of the human person (Catholic Franciscan Tradition, 2017). The Austin Catholic Academy in the archdiocese of Detroit continues to remain Augustinian in its orientation and support (Coppens, 2015).

Accordingly, the Recoletos schools of the Order of Augustinian Recollects have started to integrate the newly-published Manual de Identitad (Identity Manual) since early 2017. The newly-standardized branding system incorporated the values of its Augustinian tradition and distinguished itself from the Order of St. Augustine (Order of Augustinian Recollects, 2016).

Moore and Reid (1988) claimed that brands and branding are as old as our civilization, starting from $2250 \mathrm{BCE}$ in the Indus Valley (the modern-day India) to 300 BCE in Greece through the use of "proto-brands" (Briciu \& Briciu, 2016). The former also listed down some studies on brand-related concepts, but "brand experience" was not in the list despite the fact that contemporary branding theories had their starting point in the 1950s.

Ortmeyer and Huber pioneered the studies of the concept of "brand experience" in their 1991 paper (Khan \& Rahman, 2015). Brakus et al. (2009) conceptualized and measured "brand experience". They highlighted its sensory, affective, cognitive, and behavioral dimensions (Brakus et al., 2009; Özyer, 2016). However, this conceptualization drew various reactions. Al Mandil and Yen (2017) said it was inadequate. Other theorists made some proposals for enrichment: Nysveen and Pedersen (2013) added the relational dimension; Chevtchouk et al. (2017) included the social/relational, formative, and ABC (affective, behavioral and cognitive) components; and Andreini et al. (2017) advanced the cultural and relational dimensions.

However, Brakus et al. (2009) continued to influence several research enthusiasts. Lin (2015) studied the role of innovating brand experience in an airline industry in Taiwan. Neves, Bizarrias, da Silva, and Ferreira (2017) analyzed the relationship of brand experience in the mobile industry in Brazil. The study of Nadiah, Nadzri and Musa (2014) recommended an innovation in car industry that could be a tool for a comprehensive brand experience.

Khan and Rahman's paper (2015) offered statistical comparisons on various research areas concerning brand experience, and their recommendations had greatly 
shaped this study, with the application of brand experience to Recoletos Education. As regards Recoletos Education whose roots could be traced to the 1647 youth apostolate in Costa Rica, Cuesta (2015) presented the $19^{\text {th }}$-century OAR evangelization program to situate the initial attempts at doing apostolate in a formal school setting.

In the Philippines, a network of Recoletos schools was gradually formed under the SEAP (Secretariat of Educational Apostolate of the Philippines) which became REAP (Recoletos Educational Apostolate in the Philippines) in 2010. Around this time, in the Order, the schools were considered among the major and most needed platforms for the New Evangelization and for propagating the OAR charism (Order of Augustinian Recollects, 2010). In the Recollect Province of St. Ezekiel, the move for 'One Recoletos Education' gained momentum (Messages, Ordinances \& Elections, 2012).

The revised Constitutions of the Order (2012) added the phrase "in harmony with the charism of the Order" to the nature of the Recoletos educational apostolate to explicitly recognize its pertinence to the charism of the OAR. The said charism constitutes the three faces of the same love: amor castus ("chaste love" or contemplation), amor ordinatus ("ordered love" or fraternal love of the community), and amor diffusivus ("diffusive love" which is best shown in apostolate). They correspond to the contemplative, communitarian, and apostolic character of the OAR charism which is "our continuing identity during a process of change" (Commission on the Process of Revitalization and Restructuring, 2013).

Cuesta's (2012) descriptions of the Recoletos friars living out their threefold charism are the same descriptions that must permeate in their educational apostolate. These concretely project the Augustinian Recollects as the heart (love), the fire (passion), the arrow (service), the book (search), and the children of St. Augustine (Order of Augustinian Recollects, 2016).

The Educational Plan of the Order also outlined the proper character of Recoletos Education whose mission lies in the integral education of the human person and whose vision states that educational institutions be inspired by Augustinian pedagogy and Recollect spirituality (Order of Augustinian Recollects, 2015).

More specifically, Recoletos Education is ramified in the articulation of what is now called "Graduate Attributes of the OAR Schools" in the Philippines. These attributes are concrete expressions of St. Augustine's "Caritas et Scientia". Besana (2017) and Marcos (2015) retrieved St. Augustine's educational philosophy in his Letter 55: "Let knowledge be used as a kind of scaffolding to help build the edifice of love and understanding, which shall endure forever even after knowledge itself passes away."

The Recoletos Graduate Attributes (2015) blend both the Catholic Attributes (orthodoxy in Catholic doctrine, integrity in moral life, and dynamism in prayer life) and the Recoletos Attributes (contemplative, communitarian, apostolic, and Marian attribute which embodies all those three).

\subsection{Methodology}

This qualitative study employed the dynamic orientation of interpretative phenomenological analysis (IPA) which requires a two-stage hermeneutic: the participants interpret their lived experience, and the researcher interprets the participants' interpretation of their lived experience (Smith \& Eatough, 2012; Smith \& 
Osborn, 2008). In this way, it was desired that the embedded meaning of the brand experience of Recoletos Education as a lived-experience would be revealed.

As a method, IPA is grounded in three key positions: phenomenology, hermeneutics, and idiography. Phenomenology deals with the structures of consciousness as experienced from the first-person point of view (Smith, 2013/2016). Hermeneutics refers to the practice and process of interpretation. In IPA, the circularity of interpretation allows the emergence of truth and its multilayered context on the partwhole coherence of the text (Smith et al., 2009). Idiography is a method that focuses on the individual or particular. IPA's commitment to the individual participant lies on its keenness for details, depth of analysis, and particular context (Smith et al., 2009).

The four participants of this study were selected by way of homogeneous sampling on the basis that they could grant access to a particular perspective in making sense of their brand experience of Recoletos Education (Smith et al., 2009). Following Robinson (2014), the type of sample homogeneity is that of life history homogeneity because the participants shared a common past life experience which consisted of their relatively longer connection with any of the Recoletos schools and their familiarity with Recoletos Education.

To have four participants is well within the IPA acceptable number (Reid et al., 2005; Smith \& Osborn, 2008) particularly for a PhD study (Smith et al., 2009). In IPA, "sacrificing breadth for depth" means that "a very small number of participants" will allow "sufficient in-depth engagement with each individual case" and "a detailed examination of similarity and difference, convergence and divergence" (Smith \& Osborn, 2008). The issue is quality, not quantity. For accuracy and plausibility of the transcribed data, the participants were also given the opportunity for member checks (Creswell, 2012; Vagle, 2014).

Moreover, ethical requirements such as the informed consent of the participants, anonymity, and confidentiality were conscientiously complied with.

Prior to the commencement of data gathering, I informed all the participants who had consented to the interview about the style of interview including some background information, the use of devices, techniques, and strategies (Alase, 2017). They were given a copy of the interview schedule (Smith et al., 2009). During the interview held at an agreed time and place, two audio-recording devices and the traditional "note and pen" were used.

Data collection was accomplished following the guidelines set particularly by Smith and Osborn (2008). An interview schedule - with two questions on which followups and probes depended - was constructed and given ahead to the participants.

Faithful to the interview protocol, the interview was smoothly conducted observing the rhythm of interaction (Smith et al., 2009). The verbatim transcription of the recorded data was conducted in four phases (Blore, 2012): the "everything audible" version; the "cleaned and confidentialized" version; the "validated" version; and the IPA format. Incorporating the required notations, the second and third were returned to the participants for checking and validation. The fourth transcript was IPA-ready.

To establish validity and quality of this study, I used the four criteria or principles set by Yardley (2000) and Yardley (2015), which were also used by Smith et al. (2009): sensitivity to context, commitment and rigour, transparency and coherence, and impact and importance. 
Data analysis was committed "to an understanding of the participant's point of view and a psychological focus on personal meaning-making in particular contexts" (Smith et al., 2009 cited in Rivituso, 2014). Thus, the seven "steps to analysis" (Smith et al., 2009) were followed: (i) reading and re-reading; (ii) initial noting; (iii) developing emergent themes; (iv) searching for connections across emergent themes; (v) moving to the next case; (vi) looking for patterns across cases; and (vii) taking interpretations to deeper levels.

Writing the narrative account, I mixed extracts from participants' own words with interpretative comments in order "to retain some of the 'voice' of the participant and at the same time to enable the reader to assess the pertinence of the interpretations" (Shinebourne, 2011).

\subsection{Results and Discussion}

Individual Sense-making. The results section has two parts. The first part presents the key findings on how the individual participants make sense of their brand experience of Recoletos Education in the light of the superordinate and subordinate themes. The second part presents my own sense-making by interpreting the superordinate themes across participants.

The key findings on the individual participants' sense-making:

Rita. Her view of Recoletos Education is summarized in these words: "I consider Recoletos brand of education as personalized... not concerned only about the mind but also of the heart." It's different from other school brands where she was exposed to: "sa atmosphere lang daan" (in terms of atmosphere alone) ... "diperensya gyud "(there's a difference) ... For her, the brand-related stimuli function as a reminder to act accordingly: "when I see the heart, I tell myself I should be willing to give more of service more of my resources."

Nikko. Immersed in different contexts and in various capacities, Nikko shared his personal journey in knowing Recoletos Education. It began as a newbie in a Recoletos school when "I really didn't have any idea about the brand" to a later realization of an unconscious assimilation of the brand: "unaware ko ana nga mao na diay to akong nalearn" (I was so unaware of it that that was it already which I had learned), and then, to the state of transmitting what he had understood about the brand: "in my little ways no... ako na siyang gi-adapt ako ng gi-apply through unsa sad ang akoang passion no..." (in my little ways, I tried to adapt and apply it through expressing my passion for the tasks I do ...).

Cindy. The influence of her family to her schooling was pivotal. Her parents, her husband, her husband's parents were all products of Recoletos Education: "Ti kun anhon mo ya both sides ya naga-angot ang Recoletos. [ ] Daw pamilya..." (Any way you look at it both sides are connected to Recoletos. [ ] It's like a family). As a parent, she also introduced her child to Recoletos Education because she herself was satisfied: 
"[ ] what I have become produkto ni sya sang (is a product of) Recoletos brand of education." Consequently, "wala na kami iban sang ina balang napensaran nga diin pa sya makadto" (we no longer consider any school where to enroll our child at).

Zekiel. The family's religious background and his connection to a Recoletos school during high school allowed him to familiarize the school brand, albeit through a process: "Before kasi you do not know what does it mean. Zero $e$. [ ] Now you know that once you see a book it talks about the truth about Jesus about the scripture. And then the heart there is about charity... love that is pierced by the Lord God". The earlier Zekiel struggled to capture what Recoletos Education was, but the latter Zekiel claimed that the brand whose "core is the Caritas et Scientia" is linked to the mission to know and love Jesus: "Because of the caritas [ ]... and truth who is Jesus..."

Superordinate Themes. To capture the richness of the participants' sensemaking, the researcher in his sense-making appealed to the use of metaphors (Blore, 2012) which were taken from relevant Gospel narratives.

The house on rock (cf. Mt. 7:25). This was drawn from two subordinate themes: (a) basic features of Recoletos Education in general and (b) basic features of stimuli related to Recoletos Education. They point to the intrinsic and essential attributes of the Recoletos Education which create a highly favorable impact on the lives of stakeholders.

The basic features of Recoletos Education in general included: transformative character of the brand, link-up between core values with school brand, capacity to meet customer's expectation, and legacy to stakeholders. For instance: Nikko's realization of an acquired moral backbone was through the school's core values and brand: "unaware ko ana nga mao na diay to akong na-learn sa akong college life" (I was unaware of it when I was still working that it was already what I had learned from college life). Cindy, for her part, was grateful at the trajectory of how she has become as a human person: "what I have become produkto ni sya sang (is the product of) Recoletos brand of education."

The basic features of stimuli related to Recoletos Education were multidimensionality, encapsulation of educational itinerary, representation of integral development, and implementation of religious activities. With reference to multidimensionality, Rita confessed how she was also "pierced" to intensify her service of charity and generosity: "...when I see the heart I tell myself I should be willing to give more of service [ ] A reminder that you are not alone, you are working with people [ ]." These multiple dimensions ("see" for sensory, "willing to give" for behavioral, "reminder" for cognitive, etc.) allowed Rita to realize that her true Christian identity is always intersubjective: "No one lives for himself alone" (Romans 14:7).

The shepherd with his flock (cf. Jn. 10:27). The themes that were "synergistically" linked to one another: agents of Recoletos Education, attributes in support of Recoletos Education, and awareness of Recoletos Education. They imply system of management ("shepherding"); hence, the school brand requires mutual nourishment of relationship from top management down. 
As to the agents, the significant themes were: concerted efforts of OAR schools, involvement of the academic community, role of REAP, and Recollect priests as guide. In short, it's everybody's concern. Rita noted: "Murag makakita ka nga (You can almost see how) everybody is striving towards that direction [ ]." For Nikko, the involvement is: "tanan ("everybody")... the whole community ..."

Table 1. The Superordinate and Subordinate Themes

\begin{tabular}{c|ll}
\hline Superordinate Themes & \multicolumn{1}{c}{ Subordinate Themes } \\
\hline 1. The house on rock & - $\begin{array}{l}\text { Basic features of Recoletos Education in } \\
\text { general }\end{array}$ \\
Basic features of stimuli related to Reco- \\
letos Education
\end{tabular}

As to attributes, the significant themes were: taking the relevant and responsive direction, top management's use of technology as bridge to other stakeholders, exercise of authority based on objective criteria, and continuity and improvement. Cindy, for example, made reference to the exercise of authority based on objective criteria: "[ ] indi gale pamanggaranon manggaranon ini." ([ ] indeed this is not about being rich).

As to awareness, the significant themes were: immersion into different school climates, awakened amidst conflict of values and/or culture, from being a beneficiary to being a witness of the school brand, and triggered by a direct and personal question. Zekiel disclosed: "One of the questions asked during the group discussion among the students was: 'What makes you different from other schools?' That that was the only time that made me think: Oo nga ano! (Yeah, right!)".

The good fruit (cf. Lk. 6:43). The subordinate themes under this were the dimensions of Recoletos Education: spiritual, socio-communitarian, communicative, and cultural dimensions. They (as fruit) manifest not only the source (tree), but also the quality of that source (Recoletos Education).

As to the spiritual dimension, the significant themes were: icons of living a holy life, influence of the school in inculcating values, gaining strong foundation on the doctrinal and contemplative attributes of the school brand, and God-centeredness. Rita, 
for instance, spoke of the icons of living a holy life: “...through Our Lady of Consolation and St. Augustine we convey to the students that we have to search for the truth bitaw (to really search for the truth). [ ] "we have to aim for heaven."

As to the socio-communitarian dimension, the significant themes were: concern for others, Recoletos schools as my home, and positive reinforcement from Students' Congress of Recollect Schools (SCORES). Zekiel pointed out: "by continuing the SCORES in a way we are ah... living up or living out what we are telling the students that our school is Recollect. It has a communitarian character."

As to the communicative dimension, the significant themes were: wearing of sotana, maximization of the use of technology, role of parents, and provision of orientation program. Nikko, for example, stressed: "Dili lang sa TV but maybe sa atong mga page (Not only in TV but also in our page)... social media [ ]".

As to the cultural dimension, the significant themes were: exhibiting preferred qualities in the workplace, unconditional service, and willing to go extra mile in service of others. Rita and Cindy noted the characteristic of Recoletos graduates. Rita vouched for it: "they prefer to have Josenian graduates because Josenian graduates are not only good intellectually but they also have that ah... collaborative spirit [ ]." Cindy reported: "ang Recoletos graduate ya kuno [ ] willing ya to go extra mile."

The strong winds and the big waves (cf. Mk. 4:37). The four participants had pointed out some challenges which comprised the single subordinate theme with these significant themes: anti-Augustinian qualities, lack of awareness on the connection of the brand-related stimuli with the school brand, lack of succession plan, and loss of spiritual practices. Zekiel, for example, said: "meeting them every year because of the reunion, and you are unhappy to hear them telling you that they are not going to confession anymore... [ ]. And that's bad." This challenge fell under the spiritual dimension. The other three corresponded to the other dimensions.

Brand Management. As a whole, these four superordinate themes begot the one single overarching theme: Key Elements in the Brand Landscape of Recoletos Education. A closer look at those superordinate themes indicated four respective salient areas in brand management, namely: brand attributes, synergy and strategy, brand experience dimensions, and brand challenges.

Brand attributes. If brand attributes "portray" and "signify" the basic nature of a brand just as "the house on rock" signifies the nature of the foundation where it is set as something solid and firm, then these said "basic features" equally signify and reveal the nature of Recoletos Education as a school brand. "So," as Steve Jobs would put it in 1997, "we have to be really clear about what we want them to know about us" (Costanzo, 2016).

Synergy and strategy. Deeper reflection on the correlation among the agents, awareness, and the attributes in support of Recoletos Education conduced, on the one hand, to the idea of "synergy" among the agents of the school brand and, on the other hand, to the idea of "strategy" through which both the attributes (i.e., knowledge, skills, 
and attitudes) in support of the brand and the awareness of that same brand are to be utilized. That relationship was mirrored in "the shepherd with his flock."

Brand experience dimensions. The emergence of the four major dimensions was indicative of the multidimensionality of experiencing Recoletos Education. These brand experience dimensions manifested the more profound reality underneath or behind this Catholic and Augustinian Recollect school brand in the same way that "the good fruit" - the chosen metaphor-manifests the good tree from where it comes. The emergence of spiritual and communicative dimensions was novel in this study.

Brand challenges. The metaphor of "the strong winds and the big waves" was picked out to graphically present "the challenges" faced by Recoletos Education as it voyages through the years. This led to the conception of "brand challenges" as a proposed construct to refer to those critical situations involving the brand in general and needing strategic efforts and abilities to constructively confront them. After all, brand challenges are opportunities not only to look around, look back, and look forward to.

As indicated by the results, the implications of this study were chiefly three:

First, two dimensions - spiritual and communicative-emerged as new additions to the current conceptualization of brand experience with eight dimensions. These new dimensions emerged as a natural offshoot in the brand experience of Recoletos Education, which is a Catholic school brand. Emphasis on transcendental values and the distinction between the media of communications as touch points and as subjective responses paved the way to the emergence of the spiritual and communicative dimensions, respectively.

Second, the analogous application of synergy in the realm of psychology in which human consciousness was construed as "the combined effect of the interactions among all the neurons" posed a reductionistic view of the human person and society as a whole. Every human being, from the Christian viewpoint, is both material and spiritual; hence, his consciousness cannot just be reduced to a mere physiological activity. If stretched to its extreme, the Marxist view of man and society would appear, in which everything is purely material and without any reference to the Divine (Lawhead, 2015).

Third, the affirmations drawn from this study were : (i) Brand management always takes into consideration the basic features of the brand and brand-related stimuli; the agents, attributes, and awareness of the brand; and the various dimensions of brand experience; (ii) No brand activity is insulated, to some extent, from challenges either from within or from outside the institution; and (iii) With all those brand experience dimensions, the evangelizing stature of Recoletos Education was also revealed.

\subsection{Conclusion}

Convergent and divergent areas articulated were unveiled in the sense-making of the participants immersed in the brand experience of Recoletos Education.

The brand attributes, synergy and strategy, brand experience dimensions, and brand challenges were the key elements implicitly operational in the brand landscape 
of Recoletos Education unveiled by the researcher's interpretation of the participants' sense-making of their lived experience.

I recommended that a Brand Management Team both on the level of the Province and on the school level may be created and tasked to make strategic approaches to "revitalize and restructure" the brand, Recoletos Education. Also, a survey instrument may be crafted to determine the extent of awareness of Recoletos Education as a brand. In addition, a similar study be replicated either by using bigger number of samples (ranging from 8 to 15) coming from the same Recoletos school, or by involving those who are indirectly connected to, but within the area of, a Recoletos school such as the stakeholders from non-Recoletos schools, non-Catholic and/or nonChristian residents, jeepney drivers, sidewalk vendors, etc.

\section{REFERENCES}

Alase, A. (2017). The Interpretative Phenomenological Analysis (IPA): A Guide to a Good Qualitative Research Approach. International Journal of Education and Literacy Studies, 5(2), 9-19. Retrieved from http://dx.doi.org/10.7575/aiac.ijels.v.5n.2p.9

Al Mandil, K., \& Yen, D. (2017). From Brand Experience to Happiness: Exploring the Impacts on Brand Loyalty and Price Premium. Conference Proceedings of the $12^{\text {th }}$ Global Brand Conference of the Academy of Marketing, 278-285. School of Business and Economics, Linnaeus University, Kalmar (Sweden), 26-28 April 2017. Retrieved from https://Itu.divaportal.org/smash/get/diva2:1096843/FULLTEXT01.pdf

Andreine, D., Solerio, C., Pedeliento, G., \& Zarantonello, L. (2017) Brand experience: a multiperspective analysis. Conference Proceedings of the $12^{\text {th }}$ Global Brand Conference of the Academy of Marketing, 36-41. School of Business and Economics, Linnaeus University, Kalmar (Sweden), 26-28 April 2017. Retrieved from https://Itu.diva-portal.org/smash/ get/diva2:1096843/FULLTEXT01.pdf

Ateneo de Manila University. (n.d.). Brand Standards Manual [PDF document]. Retrieved from www.ateneo.edu/sites/default/files/Brand\%20Standards\%20Manual.pdf

Besana, D. (2017). Caritas et Scientia: The Pillars of Augustinian Recollect Education. (Unpublished doctoral dissertation). St. Louis University, Baguio City.

Blore, D. C. (2012). An Interpretative Phenomenological Analysis (IPA). Investigation of Positive Psychological Change (PPC), Including Post Traumatic Growth (PTG). (Doctoral Dissertation). University of Birmingham Research Archive. Retrieved frometheses.bham. ac.uk/3328/1/Blore_12_PhD.pdf

Bock, D. E., Poole, S. M., \& Joseph, M. (2014). Does branding impact student recruitment: A critical evaluation. Journal of Marketing for Higher Education, 24,11-21. doi:10.1080/08 841241.2014 .908454

Brakus, J. J., Schmitt, B. H., \& Zarantonello, L. (2009). Brand Experience: What Is It? How Is It Measured? Does It Affect Loyalty? Journal of Marketing, 73(3), 52-68. https://doi. org/10.1509/jmkg.73.3.52

Briciu, V. -A., \& Briciu, A. (2016). A Brief History of Brands and the Evolution of Place Branding. Bulletin of the Transilvania University of Brasov [Series VII: Social Sciences. Law], 9(2), 137-142. 
Burton, C. (2016, June 13). Catholic School Branding, Charism, and the Community Voice in the School Logo Design. Retrieved from https://www.schoolbrandingmatters. co.nz/2016/06/13/the-community-voice-in-a-school-logo-design/

Burton, C. (2017, March 31). Is school branding different from commercial branding? Retrieved from https://www.schoolbrandingmatters.co.nz/2017/03/31/school-branding-differentcommercial-branding/

Catholic Franciscan Tradition. (2017). Retrieved from https://www.siena.edu/about/aboutsiena/catholic-franciscan-tradition

Chen, C. F., \& Chen, C. F. (2014). The effect of higher education brand images on satisfaction and lifetime value from students' viewpoint. Anthropologist, 17, 137-145. Retrieved from http://www.krepublishers.com

Chevtchouk, Y., Veloutsou, C., \& Paton R. (2017). Towards a definition of brand experience: an interdisciplinary perspective. Conference Proceedings of the $12^{\text {th }} \mathrm{Global}$ Brand Conference of the Academy of Marketing, 127-134. School of Business and Economics, Linnaeus University, Kalmar (Sweden), 26-28 April 2017. Retrieved from https://Itu.diva-portal.org/ smash/get/diva2:1096843/FULLTEXT01.pdf

Commission on the Process of Revitalization and Restructuring (2013). Document 6: Beauty ever ancient and ever new...": Charism as a factor in revitalization. In A. P. Irineo (Ed.), Bulletin of the Province of St. Ezekiel Moreno, 14(21), 133-179.

Constitutions of the Order of Augustinian Recollects [Const.]. (2012). Rome.

Coppens, J. (2015). Executive Summary. Austin Catholic Academy. [PDF document, pp. 1-7] Retrieved from https://www.advanc-ed.org/

Costanzo, M. (2016, August 11). How Steve Jobs really helped Apple get back to basics. (para. 10). Retrieved at https://seekingwisdom.io/how-steve-jobs-helped-apple-get-back-to-basics-bcdfa90bb93a

Creswell, J. W. (2012). Educational Research: Planning, conducting, and evaluating quantitative and qualitative research ( $4^{\text {th }}$ ed.). Boston, MA: Pearson Education.

Cuesta, A. M. (2012). Document 5: Revitalization of the Order. The Voice of History. In A. P. Irineo (Ed.), Bulletin of the Province of St. Ezekiel Moreno, 14(21), 25-46.

Cuesta. A. M. (2015). Historia de los Agustinos Recoletos. (Vol. II. El Siglo XIX). Madrid: Institutum Spiritualitatis et Historiae Augustinianorum Recollectorum

DiMartino, C., \& Jessen, S. B., (2014). School brand management: The policies, practices, and perceptions of branding and marketing in New York City's public high schools. Urban Education. Advance online publication.doi:0042085914543112

Gwal, A. \& Gwal, R. (2016). Brewing Brand Loyalty through Experience: The CCD Way. LBS Journal of Management and Research, 14(1), 8-22. doi: 10.5958/0974-1852.2016.00002.X

Khan, I. \& Rahman, Z. (2015). A review and future directions of brand experience research. International Strategic Management Review, 3, 1-14. doi.org/10.1016/j.ism.2015.09.003

Lawhead, William (2015). The Voyage of Discovery. A Historical Introduction to Philosophy. (4 ${ }^{\text {th }}$ ed.). Connecticut: Cengage Learning 
Lin, Y. H. (2015). Innovative brand experience's influence on brand equity and brand satisfaction. Journal of Business Research 68(11), 2254-2259. doi.org/10.1016/j.jbusres.2015.06.007

Madrigal, D. (2017). Responding to the Challenges of Employment through Graduate Attributes. Recoletos Multidisciplinary Research Journal, 3(1). Retrieved from https:// rmrj.usjr.edu.ph/index.php/RMRJ/article/view/25

Malik, S. A., Mushtaq, A., Jaswal, L. H., \& Malik, S. A. (2015). Survey on marketing tactics used to build private school image and increase parents' loyalty. International Journal of Management in Education, 9, 180-199. Retrieved from www.inderscienceonline.com

Marcos, J. (2015). St. Augustine's Caritas et Scientia. Retrieved from sscrmnl.edu.ph/wp-content/ uploads/2014/.../Caritas-et-Scientia.pdf

Messages, Ordinances \& Elections of the Fifth Provincial Chapter. (2012). Province of St. Ezekiel Moreno, Quezon City.

Moore, K., \& Reid, S. E. (1988, July). The Birth of Brand: 4000 Years of Branding History. Business History, 4, 419-432. Retrieved from http://mpra.ub.uni-muenchen.de/10169/

Nadiah, W., Nadzri, M. \& Musa, R. (2014). Focus group Method an Aid to Explore Brand Experience and Contextual factors. Procedia - Social and Behavioral Sciences 130, 439-446. doi: 10.1016/j.sbspro.2014.04.051

Neves, F.V., Bizarrias, F. S., da Silva, J. G., \& Ferreira, M. C. O. (2017). A influência da relação afetiva e experiencial no processo de criação de lealdade: uma análise do mercado de telefonía móvel no Brasil. Revista Ciências Administrativas, 23(1), 156-185. doi.org/10.5020/23180722.23.1.156-185

Nysveen, H., \& Pedersen, P. E. (2013). Brand experiences in service organizations: Exploring the individual effects of brand experience dimensions. Journal of Brand Management, 20, 404-423.

Opie, J., Southcott, J., \& Deppeler, J. (2017). "It helps if you are a loud person": Listening to the Voice of a School Student with a Vision Impairment. The Qualitative Report, 22(9), 23692384. Retrieved from http://nsuworks.no va.edu/tqr/vol22/iss9/

Order of Augustinian Recollects [OAR]. (2010). Message \& Determinations of the $54^{\text {th }}$ General Chapter. Monachil, Granada, Spain.

Order of Augustinian Recollects [OAR]. (2015). Educational Plan of the Order of Augustinian Recollects. Rome.

Order of Augustinian Recollects [OAR]. (2016). Manual de Identitad. Marca de Normalización de la Marca Agustinos Recoletos. Retrieved from http://www.agustinosrecoletos.com/ download/nuevo-manual-identidad-oar/

Ortmeyer, G., and Huber, J. (1991). Brand experience in moderating the negative impact of promotions. Marketing Letters 2, 35-45. doi:10.1007/BF00435194

Özyer, Y. (2016). Understanding the Impact of the Brand Experience on Brand Reputation by the Moderating Role of Technology Turbulence. International Journal of Marketing Studies, 8(1), 161-169. doi.org/10.5539/ijms.v8n1p161

Pine, B. J., \& Gilmore, J.H. (2013). The experience economy: past, present and future. Retrieved from https://www.researchgate.net/publication/260917972

Recoletos Graduate Attributes. (2015, July-December). The Recoletos Observer, 16(3-4), 11. 
Région Lasallienne de l'Amérique du Nord (RELAN). (2012). Lasallian Education Brand Guide, 1-12. Retrieved from https://lasallian.info/wp-content/uploads/2012/08/Brand-Guide-June-2012.pdf

Reid, K., Flowers, P., \& Larkin, M. (2005). Exploring lived experience: An introduction to Interpretative Phenomenological Analysis. The Psychologist, 18 (20-23). Retrieved from https://www.academia.edu/1302205/Exploring_lived_experience

Rivituso, J. (2014). Cyberbullying Victimization among College Students: An Interpretive Phenomenological Analysis. Journal of Information Systems Education, 25(1), 71-75. Retrieved from http://jise.org/Volume25/25-1/pdf/Vol25-1pg71.pdf.

Robinson, O. (2014). Sampling in interview-based qualitative research: A theoretical and practical guide. Qualitative Research in Psychology, 11(1), 25-41. doi:10.1080/14780887.2013.801543

Rodriguez, D. H. (2016). Interpretive Phenomenological Analysis of Student Perceptions of Bullying Based on Family, School, and Media Influences, 1-127. (Doctoral Dissertation). University of New Orleans. Retrieved from http://scholarworks.uno.edu/td/2286/

Shinebourne, P. (2011). Interpretative Phenomenological Analysis. In N. Frost (Ed.), Qualitative Research Methods in Psychology. Combining Core Approaches. Berkshire, England: Open University Press. (pp. 44-64).

Smith, D. W. (2013/2016). Phenomenology. In E. N. Zalta (Ed.), Stanford Encyclopedia of Philosophy. Retrieved from https://plato.stanford.edu/entries/phenomenology/

Smith, J. A. (Ed.). (2015). Qualitative Psychology: A Practical Guide to Research Methods. London: Sage.

Smith, J. A., \& Eatough, V. (2012). Interpretative phenomenological analysis. In G. Breakwell, J.A. Smith, \&D. Wright (Eds.), Research Methods in Psychology, $4^{\text {th }}$ Edition. London: Sage.

Smith, J. A., \& Osborn, M. (2008). Interpretative phenomenological analysis. In J. A. Smith (Ed.), Qualitative Psychology: A Practical Guide to Methods (pp. 53-80). London: Sage.

Smith, J. A., Flowers, P., \& Larkin, M. (2009). Interpretative Phenomenological Analysis: Theory, Method and Research. London: Sage.

Vagle, M. (2014). Crafting phenomenological research. Walnut Creek, CA: Left Coast Press. Retrieved from https://www.amazon.com/Crafting-Phenomenological-Research-MarkVagle/dp/1611323029\#reader_1611323029

Varadarajan, B. (2016). Branding Strategies of Private International Schools in India. (Doctoral dissertation). Retrieved from scholarworks.waldenu.edu/cgi/viewcontent. cgi? article $=3692 \&$ context $=$ dissertations

Xixiang, S., Gilal R. G., \&Gilal, F. G. (2016). Brand experience as a contemporary source of brand equity in 21st Century: Evidence from the Chinese consumer market. International Journal of Education and Research,4(9), 63-76. Retrieved from www.ijern.com/journal/2016/ September-2016/06.pdf

Yardley, L. (2000). Dilemmas in qualitative health research. Psychology and Health, 15(2), 215228.doi.org/10.1080/08870440008400302

Yardley, L. (2015). Demonstrating Validity in Qualitative Psychology. In J. A. Smith (Ed.). Qualitative Psychology: A Practical Guide to Research Methods (3 ${ }^{\text {rd }}$ ed., pp. 257-272). London: Sage. 